\title{
Ecological State Assessment of Urban Green Spaces Based on Remote Sensing Data. The Case of Aktobe City, Kazakhstan
}

\author{
Aigul SERGEYEVA', Altynbek KHAMIT1**, Asima KOSHIM², Murat MAKHAMBETOV¹ \\ *Corresponding author \\ ${ }^{1}$ K. Zhubanov Aktobe Regional University, Department of Geography and Tourism, Aktobe, KAZAKHSTAN \\ ${ }^{2}$ Al-Farabi Kazakh National University, Faculty of Geography and EnvironmentalDepartment of Cartography and Geoinformatics, \\ Almaty, KAZAKHSTAN \\ $\triangle$ sergeyeva.aigul@gmail.com (D) https://orcid.org/oooo-ooo2-6821-8773 \\ $\triangle$ hamitaltynbek.97@gmail.com (10 https://orcid.org/oooo-0oo2-1261-5040 \\ $\triangle$ asima.koshim@gmail.com (i) https://orcid.org/oooo-ooo2-3355-3125 \\ $\triangle$ makhambetov.murat@gmail.com (i) https://orcid.org/oooo-ooo2-8356-296X \\ DOI: 10.24193/JSSP.2021.2.02 \\ https://doi.org/10.24193/JSSP.2021.2.02
}

K e y w o r d s: urban green area, industrial enterprise, park quality, GIS methods, ecological condition, NDVI index

\begin{abstract}
A B S T RA C T
The rapid pace of urban development triggers complex problems mostly related to urban environment pollution, and shortcomings of city's improvement. The modern city is characterized by the highest man-made pressure on the natural environment, the main problems being overcrowding, lack of open-access green areas, as well as the decrease of vegetation areas, fact that does not create comfortable living conditions for urban residents. At present, remote sensing methods are some of the priority tools used in vegetation state assessment, particularly, the calculation of vegetation index (NDVI). But often, obtaining the necessary information is limited only to the analysis of satellite data, without geobotanical field surveys, which considerably increase the reliability of the detected results. In addition, the definition of dependencies when using an integrated approach of different man-affected surfaces with a different type of overgrowth within the city remains insufficiently studied. The purpose of this study is to assess the ecological condition of the green area (parks and squares) in Aktobe city. A comprehensive processing of satellite images including the calculation of NDVI index, mapping of green areas and data statistical analysis, was carried out. We learned that the average value of NDVI for green spaces in Aktobe ranges from $0,11 \mu \mathrm{m}$ to $0,47 \mu \mathrm{m}$, which allows for the categorization of planted areas by levels of photosynthetic activity, from "unsatisfactory" to "good", yet, with $59 \%$ of them in an unsatisfactory condition. This means that the city is underdeveloped in terms of modern landscape and infrastructure. The obtained results make it possible to assess the current situation, determine the dynamics of urban green spaces and optimize spatial planning measures for green space management.
\end{abstract}

\section{INTRODUCTION}

A modern city with its high diverse technology-related impact on the natural environment is deprived of comfortable living conditions for residents, as active construction and dense development of residential and non-residential buildings results in a reduction of the green space. Green areas render the city ecological stability, building up a natural and ecological framework. Ensuring the preservation of urban vegetation should be considered as an integral part of the urban landscape planning. 
However, the anthropogenic impact on the state of urban parks, squares, alleys and lawns causes a decrease in the life quality of the urban population. Atmospheric pollution, soil degradation, mechanical damage to the land, increase in urban density, etc. lead to the deterioration of the ecological state of a city and to the decrease in the living conditions of the urban population (Lechner et. al, 2015). Public urban green areas, namely parks, are considered the most important components of urban green spaces, which improve the quality of city residents' life and are under the control and management of the local authority (Romanova, 2017, Xie et. al, 2020, Connop et. al, 2016, Rahman and Zhang, 2018).

Aktobe city is one of the largest industrial regional centers in the western region, located in the central part of the Poduralsky plateau, in a plain area with an altitude of $250-400 \mathrm{~m}$. The city extends on 2.3 thousand square kilometers ( $0.8 \%$ of the territory of the Aktobe region). Compared to 2005, the population of the city grew by $57 \%$ to 497,381 people in 2020 , which indicates one of the highest growth rates of the city's development. The Ilek River and several of its tributaries flow within the city boundaries and the Aktobe and Sazdinsky water reservoirs are located nearby. Due to its location in the inner part of Eurasia and at a considerable distance from the oceans, the climate of the city is extremely continental.
Over the past decade, the ecological situation in the city of Aktobe is considered to be unfavorable. The city is characterized by a high level of air pollution due to the negative influence of industrial enterprises and road transport. Increased content of nitrogen dioxide and formaldehyde is found in the air of the city. The main sources of air pollution in the city are JSC "Aktobe Plant of Chromium Compounds", Aktobe Ferroalloy Plant, Aktobe Heat and Power Center and some other enterprises active in the metallurgical and chemical industry. According to inspections there is a constant increase in the level of carbon and nitrogen oxides emission into the atmosphere. One of the most critical problems today is the pollution with hydrogen sulfide. In 2015, there were seven cases registered on the 105-time exceed of the concentration of hydrogen sulfide norms in the air of Aktobe city. Population growth and the increasing number of cars inevitably increases the intensity of traffic flow. This factor further increases the load on the "lungs" of the city - city parks, squares and alleys, which are quite few in number, so the city administration is taking measures for landscaping, including the certification of trees. Annually, 350 hectares of forest vegetation are planted in the region, but, due to the specific character of the climatic conditions of the region, trees do not always take root (Koshim and Sergeyeva, 2014).
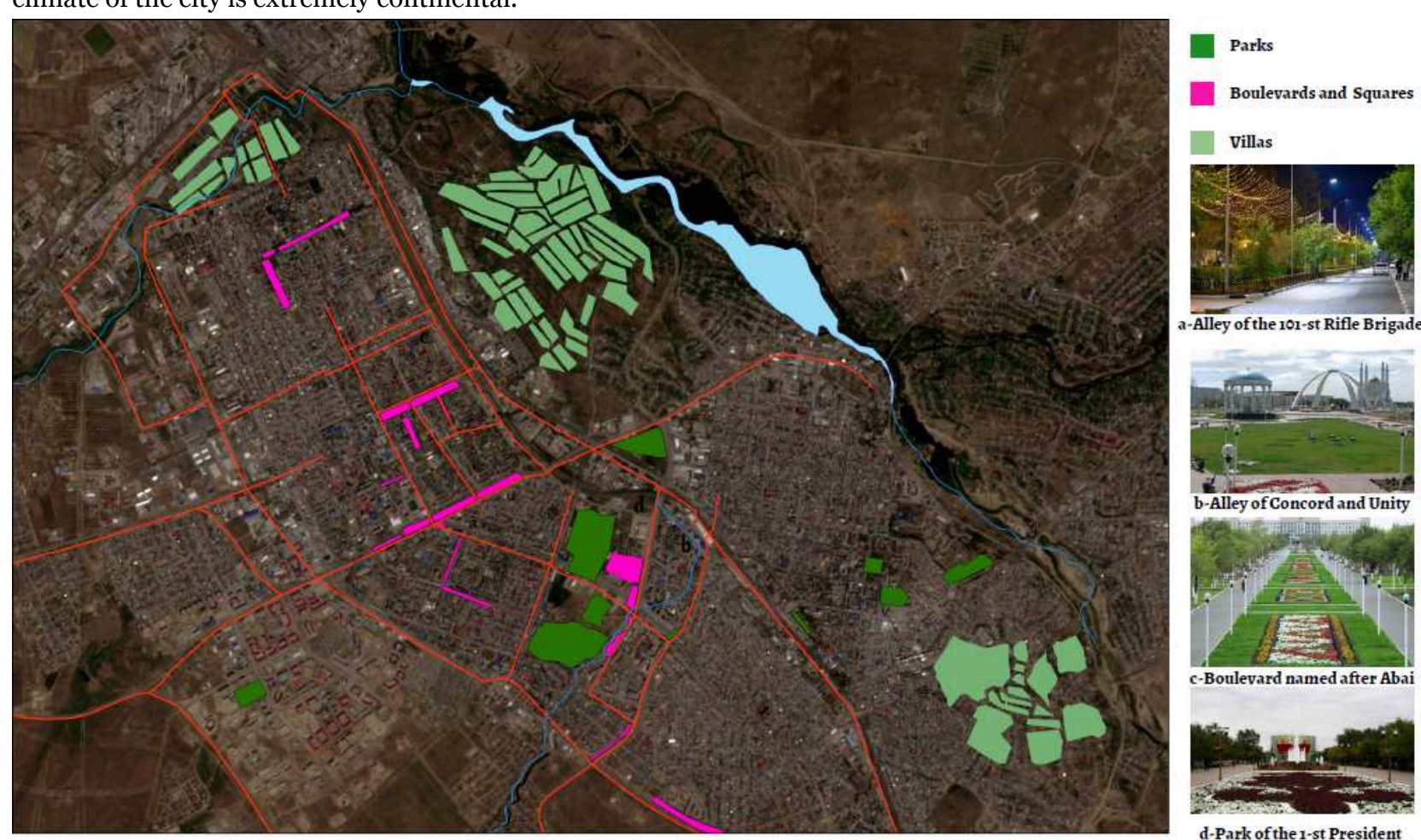

d-Park of the 1-st President

Fig. 1. The location plan of the parks in Aktobe city.

Against the background of the high growth rates of in Aktobe, accompanied by the dense urban development and extension of the network of the aboveground communication systems, the existing system network of green spaces is changing, since it is not always properly planned. The purpose of the study is to assess the environmental state of parks in the city of Aktobe using remote sensing data. As mentioned 
above, Aktobe is an industrial city, where the increase of industrial enterprises and construction of residential areas causes the decrease of green areas, including parks. This leads to the deterioration of the environmental state of the city, which is a critical problem to study. The green belt of Aktobe city is represented by artificial plantings of parks, squares, boulevards, at educational institutions, offices, sports facilities, industrial enterprises, and hedges along streets, etc. There are 22 large and small parks, squares and a boulevard in the city (Fig. 1).

The entire green area is managed by the city administration of Housing and Communal Services, which organizes actions of cleaning, landscaping and general improvement of these facilities.

\section{METHOD AND FIELD OF RESEARCH}

Over the recent decades, remote sensing technologies have largely been employed in the study of urban green spaces as they can provide recurrent and complete coverage at different spatial scales and for different seasons (Shahtahmassebi et al., 2021). Based on recent achievements such as high spatial resolution images and the policy of free access to data, remote sensing provides a valuable set of tools that can minimize the need for field research even in the case of very inhomogeneous and challenging urban environment. For example, remote sensing has been proven effective to map street trees (Li et al., 2015), detect species within urban green spaces (Demiroglu et al., 2017), map invasive shrubs (Rigolon and Németh, 2018) or assess the state of vegetation in parks (Fung and Siu, 2001).

For instance, it is necessary to understand the spatial extension, structure and composition of trees in parks so as to manage urban forest policy and administration, although current assessment methodologies vary greatly in scale, sampling intensity and tendencies (Pregitzer et al., 2019).

Over the years, many researchers have attempted to identify the components of urban parks. Among them we note urban parks, including lawns, soils and trees, buildings and other artifacts (Narh et al., 2020). Besides, the definition of urban parks is mostly influenced by zoning, guidelines and standards of planning of the city under study (Wang et al., 2021).

Urban public parks have integrated the ecological characteristics of the exchange interface among plants, soil and air, which do not only provide a relaxing environment, but also improve the urban ecological environment (Wang et al., 2018; Shikhova, 2019).

A necessary condition for the maintenance, protection and reproduction of the urban green spaces is the availability of information about the green fund. In this regard, great importance is given to up-to-date and accurate information on the state and structure of the green areas in a city. Various aspects of the analysis of urban green spaces using modern technologies are reflected in a number of publications (Lin et al., 2015; Păcurar, 2017; Nistor et al., 2019). The planning and optimization of the green framework requires having a detailed understanding of the actual distribution of vegetation, including its types, species composition, biomass, etc. In large cities, the inventories of green spaces are usually incomplete and they are rarely updated. As a rule, the control over the functional state of urban vegetation and its factors has room for improvement. Various tree species are known to have different resistance to air and environmental pollution. In this respect, remote monitoring data can be very useful to maintain the urban cadastre of green spaces, to create automated systems for their update, and also for vegetation monitoring (Cavayas et al., 2011; Pogorelov et al., 2017; Kryuchkov, 2015). The analysis of the location of green spaces and phytomass reserves, based on the calculation of the vegetation index (NDVI), makes it possible to assess the current state, the growth dynamics of the green framework of the city and optimize environmental monitoring (Kashirina et al., 2020; Tabyldina et al., 2019). Literature review revealed that data of remote sensing of the Earth are widely used to study and map the ecological state of the landscape components of the urban environment (Butt, 2018; Mougiakou and Photis, 2014; Wanghe et. al, 2020). On the territory of the city, significant areas have been allocated to the State Forest Fund to organize protective green belts, to create recreation areas in riverside areas. Protective plantings around Aktobe have begun to be created as forest crops, since 1946 . The total area of the state forest fund is of 192.5 thousand hectares, of which the forested area makes up to 40.3 thousand hectares (20.9\%). The species' composition of state plantings mainly consists of elm, maple, poplar, scots pine, black saxaul, golden currant, yellow acacia, tamarisk, silver loch, and buzzard. Along the floodplains of the Ilek River, we find black alder, poplar, tree willow, aspen, shrubs: shrub willow, acacia, rosehip, and bird cherry.

In the Old Town, middle-aged and old plantings predominate; therefore, they require constant supervision. In the New City, plantings are mostly young, and their state is mostly satisfactory. In the city, considerable attention is paid to floral decoration; however, its architectural and artistic level is not high enough. A significant disadvantage in the landscaping of the city is the lack of vertical landscaping.

Our study is based on statistical data, stock and cartographic materials, as well as materials from the official website of the Akimat of Aktobe over the recent years. Materials provided by the Department of Housing and Communal Services of Aktobe were used to assess the ecological state of the city. 
The assessment of the state of green spaces in Aktobe, including parks and alleys, was carried out with the use of remote sensing data - Sentinel-2A satellite image as of July 7, 2020 with a spatial resolution of 10 meters per pixel. Based on the image processing in the ENVI 8 program, an index of the amount of photosynthetically active biomass (NDVI) was calculated. NDVI is a normalized difference vegetation index, often called the vegetative index, which is one of the general factors considered when analyzing the vegetative state and solving quantitative issues. The independent variable is the NDVI surface area. NDVI is calculated using the standard equation (1).

$$
N D V I=N I R-\frac{R E D}{N I R}+R E D
$$

where:

- NIR is the reflection in the near infrared (IR) region of the spectrum $(0.75-1.0 \mu \mathrm{m})$;

- RED is the reflection in the red region of the spectrum (0.55-0.75 $\mu \mathrm{m})$ (Belenko, 2016).

$$
E V I=2.5 \times \frac{(N I R-R E D)}{(N I R+6 \times R E D-7.5 \times B L U E+1)} \quad(\text { Eq. 2) }
$$

To compare the vegetation index, EVI Enhanced Vegetation Index was used. It is designed as an enhancement of NDVI through the optimization of a vegetation signal in areas with a high Leaf Area Index (LAI). It is used to assess the variability of crop development both in conditions of dense vegetation canopy and in conditions of sparse vegetation.

It is proved that the ratio of these two combinations of bands strongly correlates with vegetation parameters, such as green biomass absorbed by photosynthetically active vegetation radiation. NDVI, which is a ratio of two bands, can correct possible errors caused by topography and shadow, and compensate for changes in illumination due to the terrain (Sahebjalal and Dashtekian, 2013; Huang et al., 2021). Healthy vegetation reflects strongly in the near infrared (NIR) part of the spectrum, but strongly absorbs in the visible red region (RED). On the other hand, the soil and bare ground display almost equal reflectivity in both the near infrared and red parts and have NDVI values close to 0 $\mu \mathrm{m}$. Water bodies tend to be the opposite of vegetation, and NDVI is negative. The NDVI image will significantly enhance the differentiation of vegetation canopy from the other types of surface canopy, while high values indicate temperate and tropical forests. NDVI usually varies from $0.05 \mu \mathrm{m}$ for sparse vegetation canopy to $0.7 \mu \mathrm{m}$ for dense vegetation canopy.

Based on the statistical data obtained from the Department of Architecture of the city, a list of urban parks and squares was compiled and an assessment of their current state was performed. With respect to the 86 level of environmental study of Aktobe, based on the works of previous years and the proximity of industrial complexes to green zones, the work was carried out in accordance with the requirements for large-scale mapping in the ArcGIS 10.5 program.

\section{RESULTS AND DISCUSSION}

We analyzed the existing parks based on the level of landscaping, infrastructure, frequency of visits by the population, cleanliness and design criteria, using a 5-point scale (Fig. 2).

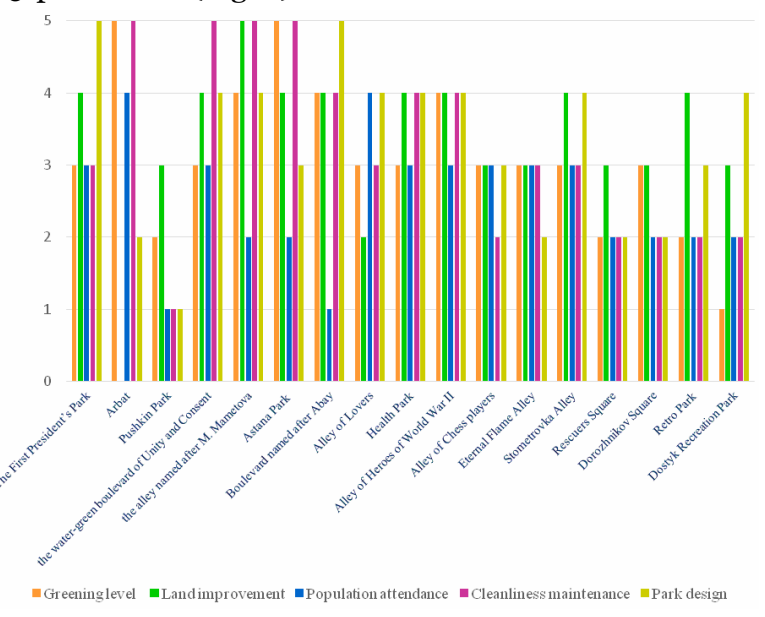

Fig. 2. Assessment chart of Aktobe parks and squares (on a 5-point scale).

As Figure 2 shows, parks and alleys located in the central part of the city are more accessible, since the active part of the city's population (youth, visitors) is located in these areas. For example, in 2018-2019, a square in Arbat and the $101^{\text {st }}$ Strelkovaya Brigada Street were rehabilitated. These two sites were not popular recreation spots before. After the reconstruction, redevelopment and renovation, these places became more in demand among the city residents. Here we see that the more correct the design and infrastructure, the more popular they become for the population. In this case, we note that the level of landscaping does not have a significant impact on popularity.

Although apart from residential areas, the parks opened on the territory of former forest belts, namely the Park of the First President, the Boulevard of Unity and Consent, the Alley named after $\mathrm{M}$. Mametova, have a rate of popularity above average. These parks are convenient for sports and walking.

Many squares and boulevards in the city are located along sidewalks. These small areas of the territory, built a long time ago, have their own historical past, so it is difficult to carry out any largescale projects on these areas, for example, to change their design. In addition to city parks, squares and alleys, green spaces are unevenly distributed as separate areas within the city, as it is seen in Table 1. Studies reveal that the history of cities, their modern development, and their landscaping are largely 
determined by the state and the features of the green spaces (La Rosa, 2014). We processed a satellite image of the city's park zones in the ArcGIS program and calculated the NDVI indicator for the city, which covered each park with a line and calculated the average vegetation level.

Table 1. Area and number of green areas by districts of Aktobe.

\begin{tabular}{|c|c|c|c|}
\hline Green areas & $\begin{array}{l}\text { Trees } \\
\text { (no.) } \\
\end{array}$ & $\begin{array}{c}\text { Grass-plat } \\
(\mathrm{sq} \mathrm{m})\end{array}$ & $\begin{array}{c}\text { Flowers } \\
(\mathrm{sq} \mathrm{m})\end{array}$ \\
\hline Bokenbaybatyr Street & 20,000 & 71,000 & 7,100 \\
\hline 12 micro region & 500 & 3,000 & 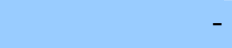 \\
\hline 11 micro region & 2,700 & 13,000 & 700 \\
\hline Old part of the city & 10,000 & 70,000 & 10,000 \\
\hline Batys-2 Micro region & 30,000 & 25,000 & 4,000 \\
\hline Aliya Moldagulova Avenue & 35,000 & 50,000 & 15,000 \\
\hline Abilaykhair Khan Avenue & 20,000 & 30,000 & 3,000 \\
\hline
\end{tabular}

Bands 4 and 8 of the Sentinel-2 image were extracted in ArcGIS using Raster Calculator and placed into the primary equation (1). The program displayed green zones depending on the range of the spectral rays and on the growth activity of vegetation.
During processing operations an assessment of green spaces was obtained and their current state was determined based on the average value of the vegetation indexes in the parks represented by polygons (Fig. 3 and Fig. 4).

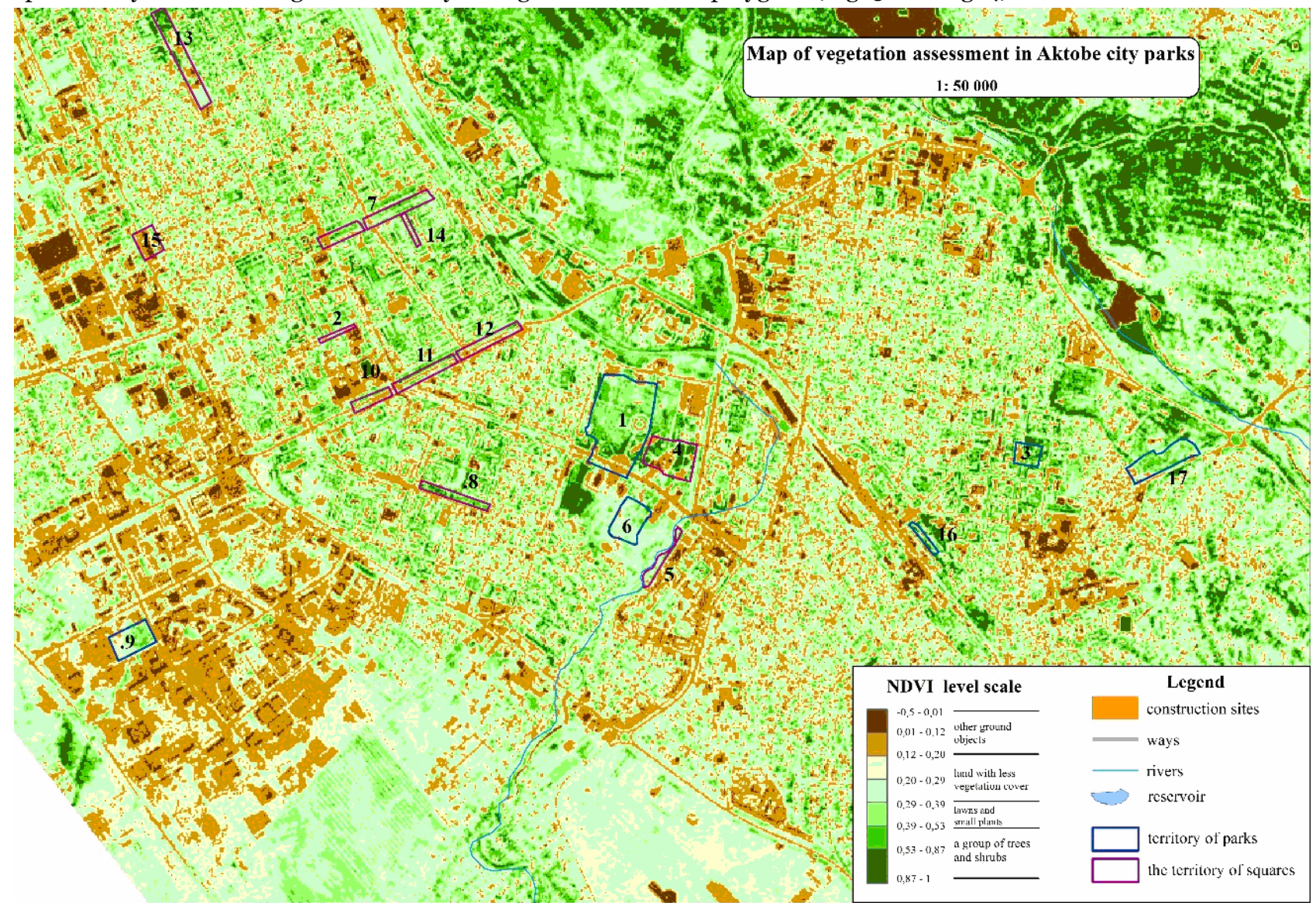

Fig. 3. Map of vegetation assessment of Aktobe city parks with NDVI index.

According to the results obtained, we can conclude that the Park of the First President recorded high values of NDVI and EVI indices (Table 2). It occupies a large area in the central part of the city and is one of the objects of high landscape significance. Its average NDVI value reached $0.46 \mu \mathrm{m}$. Most of the trees in the park are at least 10 years old and are located in the central part of the city. The landscape 
and social security of the park can be said to be average. The average NDVI value of the "Retro Park" located in the old part of the city reached $0.47 \mu \mathrm{m}$. The park dates back to Soviet times. Spruce fur, common elm and poplar grow in the area. The park is not popular among the urban community because it is one of the oldest parks in terms of infrastructure. The reeconstruction of the park without tree felling is required. The condition of the Boulevard of Unity and Harmony (Bulvar Yedinstavai Soglasiya) and the alley named after A. Moldagulova, located next to the Presidential Park, is satisfactory. About 5 to 8 years have passed since the planting of the first young plants in these locations. Thus, trees are mostly small. These alleys are decorated in a modern style, and they are the most visited places in the city in the summer. The green plants of Pushkin Park are in satisfactory condition, but it is one of the places with poor infrastructure. As the park belongs to an individual entrepreneur, because of the level of deterioration, it has been proposed to be returned into the ownership of the city public authority. According to the city's project, the park is planned to be reconstructed. The rest of the landscape features are negative. This is due to the fact that the objects are located very close to residential buildings and the areas covered by vegetation are small. To grow large trees requires a large area.

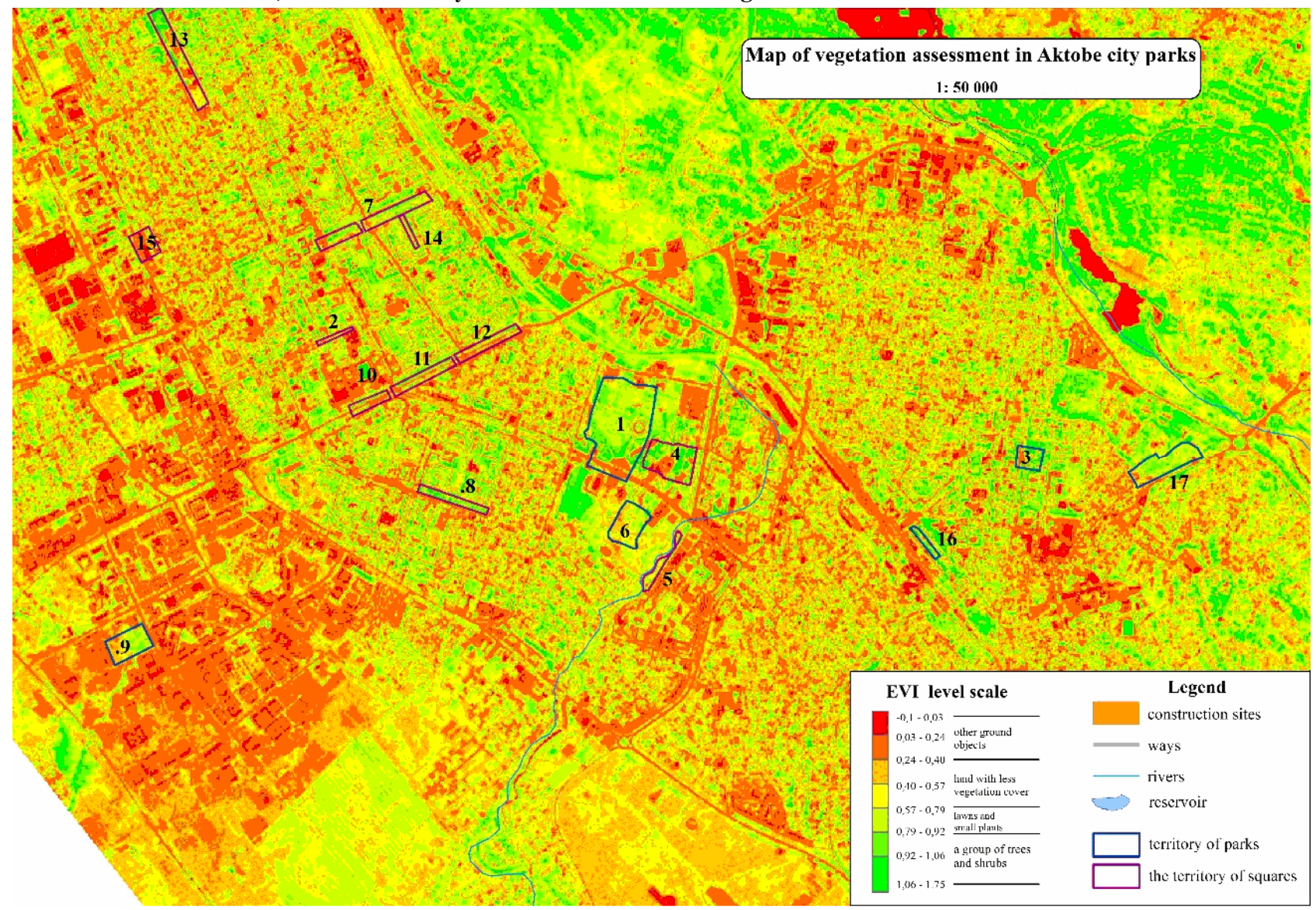

Fig. 4. The average value of the vegetation index EVI of Aktobe city parks.

In the Old Town, middle-aged and old plantings predominate; therefore, they require constant monitoring compared to younger plants as they are more often affected by harmful insects and diseases. In the New City, plantings are mostly young, in which case, the condition is mostly satisfactory. In the city, considerable attention is given to floral decoration; however, its architectural and artistic level is not high enough. A significant disadvantage is the lack of vertical landscaping in the city. Natural vegetation in the city and its suburbs grows mainly in the floodplains of the Ilek, Tamdy, Sazdy rivers and is represented by willow and poplar. To reduce the negative impact of climate conditions it is required to develop a network of protective green spaces that create the necessary microclimate of the urban area. The system of public plantings consists of plantings of citywide significance and plantings planned for residential areas. For the most part, they are represented by small islands of greenery, not connected into a single system. The most significant elements of the system are the Central City Park named after Abai in the Sazdinsky planning district and Pushkin Park in the Ileksky planning District (in the Old Town). Sanitary and protection plantings are of vital importance to isolate residential areas from large industrial zones, individual enterprises and highways. The plantings of special purpose are found 
along the streets of the city, roads and railways, in the cemeteries in the city district of Otorvanovka and on the hill behind the brick-making plant.

The positive qualities of the greening system of Aktobe city include:

- the existence of large forest parks on the gateways of the city, functioning as urban protection vegetation, which are planned to be combined into a forest park belt;

- the existence of a large Central Park named after Abai in an urban environment in the geometric center;

- the tradition to plant boulevards;

- the high quality of individual elements of the landscaping system (Karasai Batyr Boulevard, Koblandin Street);

- the availability of plantings of special purpose along most of the streets and out-of-town roads (i.e. landscaping of separate sections of the railways);

- the existence of fragments of the forest park belt, although still unconnected with each other;
- the forest park belt has significantly improved the microclimatic conditions in the city. The planting of the Zhasyl Tobe forest park has reduced the transport of dust and sand to the historical part of the city;

- latitudinal boulevards in the Sazdinsky planning area should be considered as barriers on the pathway of harmful emissions and as protection of residential buildings from the negative impact of the northern industrial zone. Considering the location of the main part of industrial enterprises, including the most environmentally hazardous ones, in the northern part of the city, the latitudinal green boulevards, which serve as barriers to emissions, are of vital importance as protection against harmful substances. Such barriers include boulevards along the Mir Avenue (near the building of the AFP House of Culture), Makhambetov Street (near the building of the A3CC House of Culture), Abay Avenue, a boulevard along the A. Moldagulova Avenue, 101st Strelkovaya Brigada Street, M. Ospanov Street and a city park in the floodplain of the Sazda River.

Table 2. The average value of the vegetation index of Aktobe city parks.

\begin{tabular}{ll|c|cc}
\multicolumn{1}{c|}{ Parks } & $\begin{array}{c}\text { NDVI average } \\
(\mu \mathrm{m})\end{array}$ & $\begin{array}{c}\text { EVI average } \\
(\mu \mathrm{m})\end{array}$ & $\begin{array}{c}\text { Vegetation } \\
\text { conditions }\end{array}$ \\
\hline 1 & The First President's Park & 0.46 & 0.81 & good \\
2 & Arbat & 0.24 & 0.38 & bad \\
3 & Pushkin Park & 0.35 & 0.54 & satisfactory \\
4 & The water-green boulevard of Unity and Consent & 0.31 & 0.58 & satisfactory \\
5 & The alley named after M. Mametova & 0.38 & 0.60 & satisfactory \\
6 & Astana Park & 0.22 & 0.41 & bad \\
7 & Boulevard named after Abay & 0.39 & 0.63 & satisfactory \\
8 & Alley of Lovers & 0.16 & 0.24 & bad \\
9 & Health Park & 0.12 & 0.21 & bad \\
10 & Alley of Heroes of the World War II & 0.3 & 0.21 & satisfactory \\
11 & Alley of Chess Players & 0.33 & 0.53 & satisfactory \\
12 & Eternal Flame Alley & 0.24 & 0.41 & bad \\
13 & Stometrovka Alley & 0.27 & 0.49 & bad \\
14 & Alley of Rescuers & 0.19 & 0.36 & bad \\
15 & Dorozhnikov Square & 0.28 & 0.47 & bad \\
16 & Retro Park & 0.47 & 0.65 & good \\
17 & Dostyk Recreation Park & 0.29 & 0.50 & satisfactory
\end{tabular}

However, the planning structure of modern Aktobe is characterized by a number of significant weak points, as follows:

- the location of auxiliary industrial, warehouse and communal structures, individual orchards and vegetable gardens in the floodplain of Ilek River;

- the placement of the main newly created complexes on the territory of the built-up part of the city;
- the isolated location of existing parks, not yet interconnected into an integrated system;

- the embankments on Ilek and Sazdy rivers have not yet benefitted from proper landscaping;

- the insufficient use of an important landscape element - the Zhasyl Tobe hill, ignoring the development of the most valuable landscape resource of the city; 
- the placement of some suburban areas in ecologically unfavorable areas of the city;

- the forest park belt around the city is still incomplete;

- some of the boulevards lack in plantings;

- the unequal distribution of public plantings on the territory of the city, in some parts of the city as Moscow and Otorvanovka being nearly absent;

- the low level of landscaping and the limited use of plantings on the territories of public and educational institutions, etc.;

- the increase of unauthorized anthropogenic development in the green areas, the construction of buildings blocking off the traffic on boulevards;

- the unauthorized residential development in the southern part of the Central Park named after Abai;

- the gradual urban development of the green belt bordering the Zhylgorodok Area in the New City. Residential buildings and garages have appeared in this area in previous years and currently the process is still ongoing. The improper location of a residential building on Sherniyaz Street overlapped Karasai Batyr Boulevard. A small canal passing through the territory of the $4^{\text {th }}$ and $5^{\text {th }}$ microdistricts is cluttered and not landscaped;

- no connection of intra-urban green spaces with the forest park belt around the city, as well as with the floodplain areas within the city limits. The existing boulevards are mainly segments of relatively small dimensions, not connected with floodplains of rivers and with each other.

In Aktobe city, the green zone is unequally distributed - the green pools located in the center and in the old part of the city have a high development density factor and a long formation period. The old part of the city is located in areas with high humidity and near water reservoirs. The facilities in the new part of the city have low rates of green spaces, but a high level of urbanization. The average NDVI value for the green spaces in Aktobe varies from $0.11 \mu \mathrm{m}$ to $0.47 \mu \mathrm{m}$, and the EVI value - from $0.19 \mu \mathrm{m}$ to $0.81 \mu \mathrm{m}$, which makes it possible to classify plant areas by levels of photosynthetic activity and, as a result, from "unsatisfactory" to "good". About 9\% of the parks in the city are conditionally good, $31 \%$ are satisfactory and $59 \%$ are unsatisfactory. It means that the city is not sufficiently developed in terms of modern landscape and infrastructure. Thus, the results obtained enable us to assess the current situation, determine the growth dynamics of urban green spaces and optimize spatial planning measures for the management of green spaces.

\section{CONCLUSIONS}

The study revealed that the NDVI and EVI values gave an equal result regarding the city's parks in terms of their numerical range. The low index of the vast majority of urban parks is directly related to the 90 plant species in the area and the high dust content of the city air. As dust settles on the surface of leaves and plants, the level of infrared rays is reduced when imaging, fact that was reflected in the satellite imagery. The location of the city in the steppe zone and the prevalence of desert-resistant and low levels chlorophyll of green vegetation also contribute to the low NDVI and EVI values.

The modern plan of Aktobe city is characterized by a number of significant shortcomings, as follows:

1). The isolated placement of existing parks that have not formed an integrated system of interconnected plantings yet;

2). No comfortable embankments on the Ilek and Sazdy rivers, the insufficient use of an important landscape element - Zhasyl-tobe hill, and the disregard of the most valuable landscape environment of the city.

3). The incompleteness of the forest-park belt around the city and along some boulevards. There is no communication between intra-urban green spaces with the forest-park belt around the city, as well as with floodplain areas within the city limits. The existing boulevards are mainly sections of relatively short dimensions, not connected with river floodplains and with each other.

We can conclude that the state of green spaces in Aktobe is quite poor, which requires taking measures. The threat to the state of the green zone is due to the intensive industrial development of the city and the development of housing construction, including the private sector. Therefore, for the systematic landscaping of the urban area and its protection requires environmental planning with preliminary research and additions to the relevant legislation on penalties for environmental offenses in the green areas of cities, as the existing regulatory framework does not guarantee effective protection of the green zone. Despite the fact that the local authorities annually allocate significant funds from the budget for the improvement of the territory, we see no results. The solution to the problem of urban greening is possible with further research using new technologies and methods with the active participation of both authorized bodies, specialists, scientists and the residents of the city.

\section{REFERENCES}

Belenko V. V. (2016), Primenenie danny`kh distanczionnogo zondirovaniya dlya kartografirovaniya zastraivaemy`kh zemel` priprovedenii geoe`kologicheskoj oczenki (Application of remote sensing data for mapping of built-up lands during the geo-ecological assessment: Tutorial). "Sputnik +" Publishing House, Moscow. [Book in Russian]. ISBN 978-5-9973-4057-5

Butt B. (2018), Environmental indicators and governance. Current Opinion in Environmental 
Ecological State Assessment of Urban Green Spaces Based on Remote Sensing Data.

The Case of Aktobe City, Kazakhstan

Journal Settlements and Spatial Planning, vol. 12, no. 2 (2021) 83-92

Sustainability, $\quad 32, \quad 84-89 . \quad$ DOI:

https://doi.org/10.1016/j.cosust.2018.05.006

Cavayas F., Ramos Y., Boyer A. (2011), Inventarizacziya gorodskikh zeleny`kh nasazhdenijiikh monitoring s ispol `zovaniem danny`kh WorldView-2 (Urban green space inventory and monitoring using WorldView-2 data). Geomatics, 3, 67-73. URL: 10kavayas_inventarizacia_gorodskikh_nasazhdeni_ikh _monitoring_worldview.pdf. Accessed on 25.03.2021. [in Russian]

Connop S., Vandergert P., Eisenberg B., Collier M. J., Nash C., Clough J., Newport D. (2016), Renaturing cities using a regionally-focused biodiversity-led multifunctional benefits approach to urban green infrastructure. Environmental Science \& Policy, 62, 99-111. https://doi.org/10.1016/j.envsci.2016.01.013

Demiroglu D., Yucekaya M., Gunaydin A., Tascioglu S. (2017), Ecological approach to urban parks: the case of urban parks in Kilis, Turkey. Fresenius Environmental Bulletin, 26(12), 7142-7149. URL: https://www.researchgate.net/publication/324974946. Accessed on 11.04.2021

Fung T., Siu W.-L. (2001), A study of green space and its changes in Hong Kong using NDVI. Geographical and Environmental Modelling, 5, 111-122. DOI: https://doi.org/10.1080/13615930120086032

Huang S., Tang L., Hupy J.P., Wang Y., Shao G. (2021), A commentary review on the use of normalized difference vegetation index (NDVI) in the era of popular remote sensing. Journal of Forestry Research, 32, 1-6. DOI: https://doi.org/10.1007/s11676-020-01155-1

Kashirina E. S., Novikov A. A., Golubeva E. I., Novikova A. M. (2020), Oczenka urovnya ozeleneniya g. Sevastopolya po danny`m distanczionnogo zondirovaniya Zemli (Evaluation of greening level of Sevastopol based on remote sensing data). Environmental Control Systems. 108-116. DOI: 10.33075/2220-5861-2020-2-108-116. [in Russian]

Koshim A. G., Sergeyeva A. M. (2014), Aqtöbe qalasynyñ aumağyn qorşağan ortanyñ lastanu deñgeilerı boiynşa audandastyru (Zoning of the city of Aktobe on the degree of pollution). Journal of Geography and Environmental Management, 2(39), 28-32. URL: https://bulletin-geography.kaznu.kz/index.php/1geo/article/view/690/576. [Article in Kazakh]

Kryuchkov A. N. (2015), Monitoring sostoyaniya gorodskikh zeleny 'khnasazhdenij kak chast' e`ffektivnogo upravleniya zeleny`mkhozyajstvom G. O. Tol yatti (Monitoring the state of urban green spaces as part of the effective management of green economy of Toliatti). Proceedings of the Samara Scientific Center of the Russian Academy of Sciences T. 17, 4(5), 1023-1028. URL: https://cyberleninka.ru/article/n/monitoringsostoyaniya-gorodskih-zelenyh-nasazhdeniy-kak-chasteffektivnogo-upravleniya-zelenym-hozyaystvom-g-otolyatti. Accessed on 19.04.2021. [in Russian]
La Rosa D. (2014), Accessibility to green spaces: GIS based indicators for sustainable planning in a dense urban context. Ecological Indicators, 42, 122-134. DOI: https://doi.org/10.1016/j.ecolind.2013.11.011

Lechner A. M., Brown G., Raymond C. M. (2015), Modeling the impact of future development and public conservation orientation on landscape connectivity for conservation planning. Landscape Ecology, 30(4), 699713. DOI: https://doi.org/10.1007/s10980-015-0153-0

Li W., Saphores, J.-D., Gillespie T. W. (2015), A comparison of the economic benefits of urban green spaces estimated with NDVI and with high-resolution land cover data. Landscape and Urban Planning, 133, 105-117. DOI: https://doi.org/10.1016/j.landurbplan.2014.09.013

Lin W., Yu T., Chang X., Wu W., Zhang Y. (2015), Calculating cooling extents of green parks using remote sensing: method and test. Landscape Urban Planning, 134, 66-75.

DOI: https://doi.org/10.1016/j.landurbplan.2014.10.012 Mougiakou E., Photis Y. N. (2014), Urban green space network evaluation and planning: optimizing accessibility based on connectivity and raster GIS analysis. European Journal of Geography, 5, 19-46. URL: https://www.researchgate.net/publication/275071168_ Urban_green_space_network_evaluation_and_plannin g_Optimizing_accessibility_based_on_connectivity_an d_raster_gis_analysis. Accessed on 22.04.2021

Narh S. N., Takyi S. A., Asibey M. O., Amponsah O. (2020), Garden city without parks: an assessment of the availability and conditions of parks in Kumasi. Urban Forestry and Urban Greening, 55, 126819. DOI: https://doi.org/10.1016/j.ufug.2020.126819

Nistor M., Nicula A. S., Haidu I., Surdu I., Carebia I., Petrea D. (2019), GIS Integration Model of Metropolitan Area Sustainability Index (MASI). The Case of Paris Metropolitan Area. Journal of Settlements and Spatial Planning, 10(1), 39-48. DOI: https://doi.org/10.24193/JSSP.2019.1.04

Păcurar B. (2017), How Green are Romania's Cities? A Quarter - Century of Green Area Policy. Journal of Settlements and Spatial Planning, 8(1), 71-77. DOI: https://doi.org/10.24193/JSSP.2017.1.06

Pogorelov A. V., Brusilo V. A., Granik N. V. (2017), Modeling city landscaping objects from mobile laser scanning data. Remote Methods of Earth Exploration, 24, 5-16. DOI:

http://doi.org/10.24057/2414-9179-2018-2-24-5-17

Pregitzer C., Ashton M., Charlop-Powers S., D'Amato A., Frey B., Gunther B., Hallett R., Pregitzer K., Woodall Ch., Bradford M. (2019), Defining and assessing urban forests to inform management and policy. Environmental Research Letters, 14(8), 085002. DOI:

https://doi.org/10.1088/1748-9326/ab2552

Rahman K., Zhang D. (2018), Analyzing the level of accessibility of public urban green spaces to different socially vulnerable groups of people. Sustainability 
(Switzerland), $\quad$ 10(11), $\quad 3917 . \quad$ DOI: https://doi.org/10.3390/su10113917

Rigolon A., Németh J. (2018), A QUalityINdex of Parks for Youth (QUINPY): Evaluating urban parks through geographic information systems. Environment and Planning B: Urban Analytics and City Science, 45(2), 275-294. DOI:

https://doi.org/10.1177/0265813516672212

Romanova E. A. (2017), Socioeconomic Conditionality of the Baltic Macroregion Landscape Development and Zoning. Journal of Settlements and Spatial Planning, 8(2), 131-137.

DOI: https://doi.org/10.24193/JSSP.2017.2.06

Sahebjalal E., Dashtekian K. (2013), Analysis of land use-land covers changes using normalized difference vegetation index (NDVI) differencing and classification methods. African Journal of Agricultural Research, 8(37), 4614 - 4622. DOI: 10.5897/AJAR11.1825

Shahtahmassebi A. R., Li C., Fan Y., Wu Y., Lin Y., Gan M., Wang K., Malik A., Blackburn G. A. (2021), Remote sensing of urban green spaces: A review. Urban Forestry and Urban Greening, 57, 126946.

DOI: https://doi.org/10.1016/j.ufug.2020.126946

Shikhova N. S. (2019), Assessment of the Functional State of Green Plantings and the Accumulation of Heavy Metals by Vegetation in Urban Green Areas for Various Purposes. Contemporary Problems of Ecology, 12(5), 502-513.

DOI: https://doi.org/10.1134/S1995425519050093

Tabyldina A. T., Kakimzhanov E. Kh., Uvarov V. N., Makash K. K. (2019), NDVI (Normalized
Difference Vegetation Index) ösımdıkter indeksın esepteu algoritımınıñ negızı (NDVI (Normalized Difference Vegetation Index)// The basis of the algorithm for calculating the index of vegetation NDVI (normalized difference vegetation index)). Journal of Geography and Environmental Management, 1 (52), 6978. Accessed on 29.04.2021 [Article in Kazakh]

Wang L., Chang J., Zheng X., Liu J. (2018), Survey of ecological environmental conditions and influential factors for public parks in Shanghai. Chemosphere, 190, 9-16. DOI: https://doi.org/10.1016/j.chemosphere.2017.09.061 Mingzhou J., Liu L., Yang Y., Zhang H. (2018), Survey of ecological environmental conditions and influential factors for public parks in Shanghai. Chemosphere, 190, 9-16. DOI: https://doi.org/10.1016/j.chemosphere.2017.09.061

Wang J., Yin P., Li D., Zheng G., Sun B. (2021), Quantitative Relationship between Urban Green Canopy Area and Urban Greening Land Area. Journal of Urban Planning and Development, 147(2), 05021016. DOI: 10.1061/(ASCE)UP.1943-5444.0000694 Wanghe K., Guo X., Wang M., Zhuang H., Ahmad S., Khan T. U., Xiao Y., Luan X., Li K. (2020), Gravity model toolbox: An automated and open-source ArcGIS tool to build and prioritize ecological corridors in urban landscapes.Global Ecology and Conservation, 22, e01012, 1-22. DOI: https://doi.org/10.1016/j.gecco.2020.e01012

Xie J., Luo S., Furuya K., Sun D. (2020), Urban Parks as Green Buffers During the COVID-19 Pandemic. Sustainability, 12(17), 6751. DOI: https://doi.org/10.339o/su12176751 